\title{
Pengaruh Rasio Keuangan TerhadapKebijakan Dividen pada Perusahaan Manufaktur yang Terdaftar di Bursa Efek Indonesia.
}

\author{
Oleh \\ Nursaada \\ Stanly Alexander \\ Novi Budiarso
}

\begin{abstract}
ABSTRAK
Tujuan dari penelitan ini adalah untuk mengetahui seberapa besar pengaruh rasio keuangan Return On Equity, Debt to Equity Ratio, Current Ratio terhadap Dividen Payout Ratio baik secara simultan maupun parsial.

Data dalam penelitian ini adalah data sekunder yang diperoleh melalui laporan tertulis berupa laporan keuangan perusahaan yang terdiri dari Neraca, Laporan Rugi/Laba, dan Laporan Perubahan Modal/Ekuitas yang diperoleh dari Bursa Efek Indonesia. Laporan Keuangan yang menjadi objek analisis diambil selama kurun waktu 2007-2010.

Metode analisis yang digunakan adalah analisis regresi linear berganda, dan untuk pengujian hipotesis digunakan pengujian statistic uji $\mathrm{F}$ dan uji t. Dengan menggunakan Software Program SPSS Version 20,0 for windows.

Pertama, statistic deskriptif. Tahap kedua, pengujian kualitas data. Tahap ketiga, melakukan uji penyimpangan asumsi klasik. Tahap keempat, melakukan analisis regresi berganda. Dan tahap kelima, melakukan pengujian hipotesis.
\end{abstract}

Kata Kunci: Rasio Keuangan, Dividen

\section{ABSTRAC}

The purpose of this research is to determine how much influence financial ratios Return On Equity , Debt to Equity Ratio , Current Ratio to Dividend Payout Ratio either simultaneously or partially .

The data in this study is a secondary data obtained through a written statement that the company's financial statements consist of the Balance Sheet, Statement of Profit / Loss and Statement of Changes in Equity / Equity obtained from the Indonesia Stock Exchange. Financial Statements which became the object of analysis is taken over the 2007-2010 period.

The analytical method used is multiple linear regression analysis, and hypothesis testing is used for testing statistical F test and t test. By using SPSS Software Version 20.0 for windows. First, descriptive statistics. The second phase, testing the quality of the data. The third phase, to test the assumptions of classical aberrations. The fourth stage, performing multiple regression analysis. And the fifth stage, hypothesis testing.

Keywords : Financial Ratios, Dividends 


\section{PENDAHULUAN}

\section{A. Latar Belakang}

Indikator kebijakan dividen yaitu Dividend Payout Ratio dan DividendYield. Penggunaan Dividend Payout Ratio sebagai indikator kebijakan dividen dalam penelitian ini dikarenakan DPR merupakan rasio keuangan yang lebih sering digunakan para investor untuk mengetahui hasil dari investasinya dan penggunaannya yang lebih sederhana dibandingkan Dividend Yield. Secara umum, penetapan kebijakan dividen dipengaruhi faktor-faktor yang dibedakan dalam dua kelompok yaitu faktor financial yang meliputi prospek pertumbuhan ,biaya modal, profitabilitas, kebutuhan pendanaan perusahaan, likuiditas, kemampuan meminjam, kebutuhan pelunasan hutang, stabilitas dividen, serta tingkat ekspansi aktiva dan faktor non financial yang meliputi peraturan perpajakan, pembatasan perjanjian hutang, peluang ke Pasar Modal, kendali perusahaan, posisi pemegang saham sebagai pembayar pajak.

Penelitian ini akan membahas faktor financial yang diukur dengan menggunakan unsur-unsur kinerja keuangan perusahaan. Kinerja keuangan perusahaan mampu memberikan gambaran baik kepada manajemen maupun para investor mengenai pertumbuhan dan perkembangan perusahaan serta kondisi keuangan perusahaan pada periode tertentu. Rasio keuangan digunakan sebagai variabel penelitian karena rasio keuangan merupakan salah satu alat analisis yang diperlukan untuk mengukur kondisi dan efisiensi operasi perusahaan dalam mencapai tujuan perusahaan yaitu laba bersih. Laba perusahaan merupakan unsur dasar kebijakan dividen perusahaan. Rasio keuangan merupakan hasil perbandingan pos-pos dalam Laporan Keuangan (financial statement) pada suatu periode tertentu.

Tiga rasio keuangan yang dipilih sebagai variabel independen dalam penelitian ini didasarkan pada faktor-faktor yang mempengaruhi kebijakan dividen yang difokuskan pada beberapa faktor financial dan merupakan penggabungan dari variabel-variabel yang digunakan dalam penelitian-penelitian terdahulu. Faktor-faktor financial tersebut meliputi:

1. Tingkat laba yang dilihat dari rasio profitabilitas yang mengukur kemampuan perusahaan dalam menghasilkan keuntungan yaitu Return On Equity. Oleh karena dividen dibagikan dari keuntungan bersih yang diperoleh perusahaan, maka besarnya keuntungan akan mempengaruhi besarnya dividen yang akan dibagikan.

2. Posisi likuiditas perusahaan yang dilihat dari rasio likuiditas yang mengukur kemampuan perusahaan dalam memenuhi kewajiban jangka pendeknya yaitu Current Ratio. Dividen merupakan aktiva lancar perusahaan sehingga kelebihan atau kekurangan aktiva lancar akan mempengaruhi kemampuan perusahaan dalam membagikan dividen.

3. Kebutuhan dana untuk melunasi hutang yang dilihat dari Debt to Equity Ratioyang mengukur besarnya hutang yang dapat dijamin dengan ekuitas perusahaan. Semakin besar hutang perusahaan maka semakin besar pula kebutuhan dana untuk melunasi hutang perusahaan sehingga dapat mempengaruhi penentuan rasio pembayaran dividennya.

Pertumbuhan sektor industri manufaktur yang tidak sesuai target yang diharapkan pada tahun 2009 disebabkan oleh beberapa hal, antara lain: kalah bersaing dengan produk impor, rendahnya produktivitas buruh, keterbatasan bahan baku, dan atau permasalahan teknologi. Padahal sektor industri manufaktur merupakan salah satu sektor andalan di Indonesia karena memberikan kontribusi paling baik dalam perekonomian Indonesia. Selain itu, terjadi perubahan bisnis-bisnis baru yang diminati oleh para investor menjadikan posisi perusahaan manufaktur menjadi lebih sulit. Hal ini dikarenakan para investor menyadari bahwa Cina sebagai raksasa manufaktur dunia sangatlah sulit dilawan. Hal inilah yang menjadi tantangan terutama bagi perusahaan manufaktur Go Public untuk berusaha mempertahankan dan mengembalikan kepercayaan para investor dengan menunjukkan kinerja yang sebaik-baiknya. 
Berdasarkan latar belakang di atas, maka pokok masalah dalam penelitian adalah: Apakah rasio keuangan berupa Current Ratio, return On Equity dan Debt to Equity Ratio mempunyai pengaruh baik terhadap Dividend Payout Ratio pada perusahaan manufaktur yang terdaftar di BEI?

Sesuai dengan permasalahan yang dikemukakan maka tujuan dari penelitan ini adalah untuk mengetahui seberapa besar pengaruh rasio keuangan Return On Equity, Debt to Equity Ratio, Current Ratio terhadap Dividen Payout Ratio baik secara simultan maupun parsial.

\section{LANDASAN TEORI}

A. Pengertian Dividen

Dividen adalah pembagian laba kepada pemegang saham berdasarkan banyaknya saham yang dimiliki. Pembagian ini akan mengurangi laba di tahan dan kas yang tersedia bagi perusahaan, tapi distribusi keuntungan kepada para pemilik memang adalah tujuan utama suatu bisnis.

Menurut Stice et al (2004:902) Dividen adalah pembagian kepada pemegang saham dari suatu perusahaan secara proporsional sesuai dengan jumlah saham yang dipegang oleh masing-masing pemilik. Sementara menurut Skousen et al (2001:757) yang dikutip oleh Manurung dan Siregar (2008:3) Dividen adalah pendistribusian laba secara proporsional kepada para pemegang saham sesuai dengan jumlah saham yang dimilikinya.

Warsono (2003:271) menjelaskan, Dividen merupakan bagian dari laba yang tersedia bagi pemegang saham biasa (earning available for common stockholder) yang dibagikan kepada para pemegang saham.Hanafi (2004:361), mengemukakan bahwa Dividen merupakan kompensasi yang diterima oleh pemegang saham, disamping capital gain. Dividen ini untuk dibagikan kepada para pemegang saham sebagai dari keuntungan dari laba perusahaan.

Dyckman,et al. (2001: 439) menjelaskan bahwa dividen merupakan distribusi laba kepada pemegang saham dalam bentuk aktiva atau saham perusahaan penerbit.

Berdasarkan pendapat-pendapat tersebut maka dapat disimpulkan bahwa dividen merupakan bagian laba yang dihasilkan oleh perusahaan, baik berasal dari laba periode saat ini ataupun laba periode sebelumnya yang dibagikan kepada pemegang saham sebagai hasil atas investasi.

Menurut Warsono (2003:275), indikator untuk mengukur kebijakan dividen yang secara luas digunakan ada dua macam, yaitu:

1. Hasil Dividen (Dividend Yield). Dividend Yield adalah suatu rasio yang menghubungkan dividen yang dibayar dengan harga saham biasa. Dividend Yield menyediakan suatu ukurankomponen pengembalian total yang dihasilkan dividen, dengan menambahkan apresiasi harga yang ada. Beberapa investor menggunakan dividend yield sebagai suatu ukuran risiko dan sebagai suatu penyaring investasi, yaitu mereka akan berusaha menginvestasikan dananya dalam saham yang menghasilkan dividend yield yang tinggi.

2. Rasio Pembayaran Dividen (Dividend Payout Ratio/DPR)

DPR merupakan rasio hasil perbandingan antara dividen dengan laba yang tersedia bagi para pemegang saham biasa. DPR banyak digunakan dalam penilaian sebagai cara pengestimasian dividen untuk periode yang akan datang, sedangkan kebanyakan analis mengestimasikan pertumbuhan dengan menggunakan laba ditahan lebih baik daripada dividen.

Bringham (2001:66) menyebutkan terdapat tiga teori dari preferensi investor mengenai kebijakan dividen dan dua isu teoritis lainnya yang dapat mempengaruhi pandangan kita terhadap kebijakan dividen yaitu : 


\section{Dividend Irrelevance Theory}

Dividend Irrelevance Theory adalah suatu teori yang menyatakan bahwa kebijakan dividen perusahaan tidak mempunyai pengaruh baik terhadap nilai perusahaan maupun biaya modalnya. Teori ini mengikuti pendapat Modigliani dan Miller yang menjelaskan bahwanilai suatu perusahaan tidak ditentukan oleh besar kecilnya Dividend Payout Ratio, tetapi ditentukan oleh laba bersih sebelum pajak dan kelas risiko perusahaan. Jadi menurut Modigliani dan Miller, teori ini tidak relevan.

2. Bird InThe Hand-Theory

Bird In Hand Theory di ungkapkan oleh Gardon dan Lintner menyatakan bahwa biaya modal sendiri perusahaan akan naik jika dividend payout rendah karena investor lebih suka menerima dividen daripada capital gain. Menurut mereka investor memandang dividend yieldlebih pasti daripada capital gain yield.

3. Signaling Hypothesis Theory

Teori ini menyatakan ada bukti empiris bahwa jika ada kenaikan dividen akan diikuti dengan kenaikan harga saham, sebaliknya jika terjadi penurunan dividen maka akan diikuti pula oleh penurunan harga saham.

4. Teori Clientele Effect

Teori ini menyatakan bahwa kelompok (clientele) pemegang saham yang berbeda akan memiliki preferensi yang berbeda terhadap kebijaksanaan perusahaan. Ada investor yang lebih menyukai memperoleh pendapatan dividen, misalnya individu yang sudah pensiun dan ada pula investor yang lebih suka menginvestasikan kembali pendapatan mereka, karena investor iniberada dalam tarif pajak yang tinggi.

5. Teori Preferensi Dividen

Menurut teori ini, investor yang memiliki sebagian besar saham mungkinlebih suka perusahaan menahan dana dan menanamkan kembali laba ke dalamperusahaan. Pertumbuhan laba dianggap menghasilkan kenaikan harga sahamdan keuntungan modal yang pajaknya rendah akan menggantikan dividen yang pajaknya lebih tinggi.

Menurut Sutrisno (2001), terdapat beberapa faktor yang mempengaruhi kebijakan dividen, yang pada dasarnya dapat dibagi menjadi dua kelompok besar, yaitu:

1. Keputusan dividen yang berasal dari lingkungan internal perusahaan atau yang dapat dikontrol manajemen, seperti posisi likuiditas, hutang, profitabilitas yang merupakan unsur dari kinerja keuangan.

2. Keputusan dividen yang dipengaruhi lingkungan eksternal perusahaan atau diluar kontrol manajemen, antara lain seperti inflasi, pajak atas dividen, hukum, dan lain sebagainya, dimana perusahaan harus selalu menyesuaikan diri terhadap perubahan faktor-faktor tersebut.

Menurut Lawrence (2003: 566) faktor-faktor yang mempengaruhi kebijakan dividen adalah:

1. Profitabilitas Kesempatan Investasi Perusahaan

Jika perusahaan tidak dapat berinvestasi pada hal yang menguntungkan maka pendapatan akan dibayarkan dalam dividen. Namun disisi lain ketika ada kesempatan investasi yang menguntungkan, pendapatan akan digunakan untuk investasi dan mungkin akan menghasilkan zero dividend payout. Pembiayaan investasi dari laba yang diperoleh (internal financing) lebih diutamakan dari pada membayar dividen dan membiayai investasi dengan mengeluarkan saham atau obligasi karena pemegang saham lebih menginginkan capital gain daripada pendapatan dividen. Selain itu, peningkatan modal eksternal melibatkan biaya transaksi yang berupaya dihindari dengan menggunakan dana internal dari operasi.

2. Peraturan Perpajakan

Peraturan perpajakan telah menetapkan pajak baik untuk dividen maupun capital gain. Pajak atas dividen lebih besar daripada pajak atas capital gain dengan beberapa alasan. 
Pertama, pajak dividen dikenakan pada seluruh dividen yang diterima. Kedua, pajak ini dibebankan pada tahun pembayaran dividen. Sedangkan pajak atas capital gain dibayarkan pada saat saham terjual dan pajak hanya dikenakan atas gain yang diperoleh investor.

3. Pertimbangan legal

Kontrak antara perusahaan dengan kreditur atau antara perusahaan dengan pemegang saham preferen merupakan hambatan bagi aktivitas perusahaan dengan tujuan untuk melindungi kreditur dan pemegang saham preferen. Karena adanya perjanjian ini maka dividen hanya dibayarkan dari laba yang dihasilkan pada periode setelah kontrak hutang efektif. Disisi lain, kontrak preferen yang menyediakan cumulative dividend menyiratkan bahwa tidakakan ada dividen untuk pemegang saham biasa sampai semua dividen saham preferen baik current dividend atau unpaid past dividend dibayarkan.

4. Kebutuhan Likuiditas

Perusahaan biasanya memegang sejumlah tertentu asset yang lancar untuk mencukupi kebutuhan kas yang direncanakan ataupun tidak. Jika perusahaan memiliki cash on hand yang besar, maka untuk menghilangkan aset liquid dan kas yang menganggur perusahaan dapat membayarkan dividen atau menggunakan dana itu untuk melunasi hutang. Di lain pihak jika perusahaan kekurangan aset yang liquid, maka perusahaan dapat menutupinya dengan membatasi atau mengurangi dividen.

5. Pertimbangan Biaya Perusahaan Dan Pemegang Saham

Perusahaan dapat mempertahankan dividend payout yang rendah untuk menghindari pembiayaan eksternal. Pembiayaan eksternal memerlukan biaya yang besar dan perusahaan akan menghindari dengan melakukan internalfinancing. Biaya transaksi internal financing yang menempati porsi besar adalah pembayaran dividen dan dapat dihindari atau dicegah dengan tidak membayar dividen.

\section{B. Kinerja Keuangan}

Kinerja merupakan pengukuran prestasi yang dapat dicapai oleh perusahaan yang mencerminkan kondisi kesehatan dari suatu perusahaan pada kurun waktu tertentu. Menurut Muchlis (2000: 44), penilaian kinerja adalah prestasi keuangan yang tergambar dalam laporan keuangan perusahaan yaitu neraca rugi-laba dan kinerja keuangan menggambarkan usaha perusahaan (operation income). Profitability suatu perusahaan dapat diukur dengan menghubungkan keuntungan yang diperoleh dari kegiatan pokok perusahaan dengan kekayaan asset yang digunakan untuk menghasilkan keuntungan. Analisis kinerja keuangan ini didasarkan pada data keuangan yang dipublikasikan, serta tercermin dalam laporan keuangan yang dibuat sesuai dengan Prinsisp Akuntansi yang Berlaku Umum (PABU)“

Untuk mengevaluasi kondisi dan kinerja keuangan suatu perusahaan, analisis keuangan harus menggunakan tolak ukur. Tolak ukur yang sering digunakan adalah rasio atau indeks yang berhubungan dengan data keuangan yang satu dengan yang lain, sehingga perlu diberikan interpretasi agar lebih mudah memahami kondisi keuangan dan kinerja perusahaan yang diperoleh dari analisis keuangan.

Berdasarkan pendapat-pendapat tersebut, kinerja keuangan dapat diartikan sebagai ukuran tingkat keberhasilan manajemen perusahaan pada saat tertentu dalam mengelola sumber daya keuangannya. Penilaian kinerja perusahaan dapat menggunakan tolak ukur analisis rasio yang didasarkan prinsip akuntansi yang lazim digunakan.

Untuk menilai kinerja perusahaan dari dimensi keuangan dapat diperoleh melalui laporan keuangan dan analisis rasio keuangan yang menunjukkan kekuatan dan kelemahan perusahaan dan sebagai alat prediksi masa depan perusahaan serta menunjukkan tingkat risiko dan peluang usaha.

\section{Analisis Rasio Keuangan}

Analisis rasio merupakan cara terpenting untuk mengutamakan hubungan-hubungan yang bermakna diantara komponen-komponen dari laporan keuangan. 
Angka rasio diperoleh dengan jalan membagi satu data dengan data lainnya. Rasiorasio keuangan biasanya dinyatakan dalam persentase $(\%)$ atau kali $(\mathrm{x})$.

Analisis rasio keuangan akan menyederhanakan informasi yang menggambarkan hubungan antara pos tertentu dengan pos lainnya yang dilaporkan.

Rasio menggambarkan suatu hubungan atau pertimbangan (mathematicalrelationship) antara suatu jumlah tertentu dengan jumlah lain dan dengan menggunakan alat analisis berupa rasio ini akan dapat menjelaskan atau memberikan gambaran kepada analis mengenai baik atau buruknya kondisi keuangan suatu perusahaan (Munawir, 2002: 64).

Berdasarkan pengertian diatas, maka dapat disimpulkan bahwa analisisrasio keuangan adalah suatu alat analisis yang dapat digunakan untuk menggambarkan dan menjelaskan kinerja serta kondisi keuangan perusahaan melalui angka-angka rasio yang telah diinterpretasikan oleh analis.

Adapun kriteria untuk menentukan sehat atau tidaknya posisi keuangan suatu perusahaan, dapat diklasifikasikan menjadi lima kelompok rasio keuangan, yaitu :

1. Rasio Likuiditas adalah suatu rasio keuangan yang menunjukkan kemampuan perusahaan untuk memenuhi kewajiban-kewajiban jangka pendeknya yang harus dipenuhi. Dalam menganalisis posisi likuiditas perusahaan dapat menggunakan dua macam rasio yaitu :

a. Rasio Lancar (Current Ratio)

Rasio Lancar $=\quad$ Aktiva Lancar

Hutang Lancar

(Sumber: Warsono, Manajemen Keuangan Perusahaan, 2003: 34)

b. Rasio Cepat (Quick or Acid Ratio)

Rasio Cepat $=\quad$ Aktiva Lancar - Persediaan

Hutang Lancar

(Sumber: Warsono, Manajemen Keuangan Perusahaan, 2003: 35)

2. Rasio Aktivitas adalah rasio keuangan yang mengukur bagaimana perusahaan mengelola aktiva-aktivanya. Dapat diukur dengan:

a. Rasio Perputaran Persediaan (Inventory Turnover/ITO)

$\mathrm{ITO}=\quad \underline{\text { Penjualan }}$

Rata - rata Persediaan

(Sumber: Warsono, Manajemen Keuangan Perusahaan, 2003: 35)

b. Perputaran Aktiva Total (Total Assets Turnover/TATO)

TATO $=\quad$ Penjualan

Total Aktiva

(Sumber: Warsono, Manajemen Keuangan Perusahaan,2003: 36)

3. Rasio Leverage/Hutang adalah rasio keuangan yang digunakan untuk

mengukur kemampuan perusahaan dalam memenuhi kewajiban-kewajibannya kepada kreditur. Dapat diukur dengan:

a. Rasio Hutang (Debt Ratio/DR)

Debt Ratio $=\quad$ Total Hutang

Total Aktiva

(Sumber: Warsono, Manajemen Keuangan Perusahaan, 2003: 37)

b. Rasio Hutang terhadap Ekuitas (Debt to Equity Ratio/DER)

DER $=\quad$ Total Hutang

Ekuitas

(Sumber: Gill dan Chatton, Memahami Laporan Keuangan, 2005: 44)

4. Rasio Profitabilitas mengukur seberapa besar kemampuan perusahaan dalam menghasilkan keuntungan. Dapat diukur dengan lima macam rasio, yaitu:

a. Rasio Margin Laba Kotor (Gross Profit Margin) 
Gross Profit Margin $=\quad \underline{\text { Laba Kotor }}$

Penjualan

(Sumber: Warsono, Manajemen Keuangan Perusahaan, 2003: 37)

b. Margin Laba Operasi Bersih (Net Operating Profit Margin)

Net Operating Profit Margin $=$ Laba Operasi Bersih(EBIT)

$$
\text { Penjualan }
$$

(Sumber: Warsono, Manajemen Keuangan Perusahaan, 2003: 37)

c. Margin Laba Bersih (Net Profit Margin)

Net Profit Margin $=\quad$ Laba Bersih

Penjualan

(Sumber: Warsono, Manajemen Keuangan Perusahaan, 2003: 37)

d. Pengembalian atas Investasi (Return On Investment/ROI)

$\mathrm{ROI}=$

$\underline{\text { Laba Bersih (EAT) }}$

Total Aktiva

(Sumber: Sawir, Analisa Kinerja Keuangan Perusahaan, 2005:19)

e. Pengembalian atas Ekuitas (Return On Equity/ROE)

$\mathrm{ROE}=\frac{\text { Laba Bersih (EAT) }}{\text { Ekuitas Saham Biasa }}$

(Sumber: Sawir, Analisa Kinerja Keuangan Perusahaan, 2005: 20)

5. Rasio Nilai Pasar memberikan suatu indikasi kepada manajemen mengenai apa yang dipikirkan oleh para investor ekuitas tentang kinerja masa lalu perusahaan dan prospeknya dimasa yang akan datang. Dapat diukur dengan:

a. Rasio Laba per Lembar Saham (Earning Per Share/EPS)

EPS $=$

Laba Bersih (Net Earning)

Jumlah Rata-rata Saham Biasa yang Beredar

(Sumber: Gill dan Chatton, Memahami Laporan Keuangan, 2005: 66)

b. Ekuitas per Lembar Saham (Equity Per Share/EqPS)

$\mathrm{EqPS}=$

Ekuitas Saham Biasa

Jumlah Saham Biasa yang Beredar

(Sumber: Warsono, Manajemen Keuangan Perusahaan, 2003: 39)

c. Dividen per Lembar Saham (Dividend Per Share/DPS)

DPS $=$

Nilai Dividen Total

Jumlah Rata-rata Saham Biasa yang Beredar

(Sumber: Warsono, Manajemen Keuangan Perusahaan, 2003: 39)

d. Rasio Harga terhadap Laba (Price to Earning Ratio/PER)

PER =

Harga per Lembar Saham

Pendapatan per Lembar Saham

(Sumber: Gill dan Chatton, Memahami Laporan Keuangan Perusahaan, 2005: 67)

e. Rasio Harga terhadap Nilai Buku (Price Book Value/PBV)

$\mathrm{PBV}=$

Harga Pasar Saham per Lembar

Nilai Buku Saham per Lembar

(Sumber: Warsono, Manajememen Keuangan Perusahaan, 2003: 39)

f. Rasio Pembayaran Dividen (Dividen Payout Ratio/DPR)

$\mathrm{DPR}=$

Total Dividen

Laba Bersih (EAT)

(Sumber: Warsono, Manajemen Keuangan Perusahaan, 2003: 40)

g. Hasil Dividen (Dividend Yield/DY)

$\mathrm{DY}=$

Dividend Per Share

Harga Pasar Saham per Lembar

(Sumber: Gill dan Chatton, Memahami Laporan Keuangan, 2005: 68 


\section{METODE PENELITIAN}

Penelitian ini dilakukan pada perusahaan manufaktur yang terdaftardi Bursa Efek Indonesia (BEI), melalui website : www.idx.co.id dan melalui situs-situs resmi perusahaan.

Data dalam penelitian ini menurut jenisnya merupakan data kuantitatif, yaitu data yang diukur dalam suatu skala numerik (angka). Menurut sumbernya, data dalam penelitian ini adalah data sekunder yang diperoleh melalui laporan tertulis berupa laporan keuangan perusahaan yang terdiri dari Neraca, Laporan Rugi/Laba, dan Laporan Perubahan Modal/Ekuitas yang diperoleh dari Bursa Efek Indonesia. Laporan Keuangan yang menjadi objek analisis diambil selama kurun waktu 2007-2010.

\section{A. Metode Analisis}

\section{Uji Asumsi Klasik}

a. Uji Normalitas

Ghozali (2009:107)uji normalitas bertujuan untuk menguji apakah dalam model regresi, variabel terikat dan variabel bebas keduanya memiliki distribusi normal atau tidak. Model regresi yang baik adalah memiliki distribusi data normal atau mendekati normal. Distribusi normal akan membentuk satu garis lurus diagonal, dan ploting data akan dibandingkan dengan dengan garis diagonal. Jika distribusi data adalah normal, maka garis yang menghubungkandata sesungguhnya akan mengikuti garis diagonalnya. Uji normalitas dalam penelitian ini dilakukan dengan menggunakan Uji Kolmogorov Smirnov.

b. Uji Multikolinearitas

Ghozali (2009:25) uji multikolinearitas bertujuan untuk menguji apakah dalam model regresi ditemukan adanya korelasi yang tinggi atau sempurna antar variabel bebas/independen.Model regresi yang baik seharusnya tidak terjadi korelasi di antara variabel bebas.Jika variabel bebas saling berkorelasi, maka variabel-variabel ini tidak ortogonal. Apabila terjadi korelasi antara variabel bebas, maka terdapat problem multikolinearitas (multiko) pada model regresi tersebut. Untuk mendeteksi ada atau tidaknya multikolinearitas yang tinggi antar variabel independen dapat dideteksi dengan cara melihat nilai tolerance dan variance inflation factor (VIF).

\section{c. Uji Autokorelasi}

Autokorelasi adalah korelasi (hubungan) yang terjadi di antara anggota-anggota dari serangkaian pengamatan yang tersusun dalam rangkaian waktu atau tersusun dalam rangkaian ruang.Autokorelasi bertujuan untuk menguji apakah dalam suatu model regresi linier ada korelasi antara kesalahan pengganggu pada periode $t$ dengan kesalahan pada periode t-1.Jika terjadi korelasi, maka dinamakan terjadi problem autokorelasi (Ghozali, 2009:79).Pengujian ini dilakukan dengan menggunakan uji Durbin-Watson (DW-test). Uji ini digunakan untuk autokorelasi tingkat satu (first order autocorrelation) dan mensyaratkan adanya intercept (konstanta) dalam model regresi dan tidak ada variabel lag diantara variabel independen. B.

\section{B. Metode Pengujian Hipotesis}

Metode analisis data yang digunakan dalam penelitian ini adalah regresi berganda, yaitu :

$$
\begin{aligned}
& \mathrm{Y}=\mathrm{a}+\mathrm{b}_{1} \mathrm{x}_{1}+\mathrm{b}_{2} \mathrm{x}_{2}+\mathrm{b} 3 \times 3 \\
& \text { Di mana : } \\
& \begin{aligned}
\mathrm{Y}=\text { Rentabilitas } \\
\mathrm{a}=\text { Konstanta } \\
\mathrm{b}_{1}-\mathrm{b}_{2}=\text { Nilai koefisien yang dicari } \\
\mathrm{X}_{1}=\text { Return On Asset } \\
\mathrm{X}_{2}=\text { Debt to Equity Ratio } \\
\mathrm{X} 3 \quad=\text { Current Ratio }
\end{aligned}
\end{aligned}
$$

a. Uji Parsial (t hitung). 
Uji t digunakan untuk menguji pengaruh variabel indenpenden terhadap variabel dependen secara parsial atau individu dengan tingkat signifikan $\alpha=5 \%$, yaitu jika $\mathrm{t}$ signifikan $>\alpha$ maka $\mathrm{HO}$ diterima dan Ha ditolak dan sebaliknya jika $\mathrm{t}$ signifikan $<\alpha$ maka H0 ditolak dan Ha diterima.

b. Uji Simultan (F hitung).

Uji $\mathrm{F}$ digunakan untuk menguji pengaruh variabel indenpenden terhadap variabel dependen secara simultan atau keseluruhan dengan tingkat signifikan $\alpha=5 \%$, yaitu jika $F$ signifikan $>\alpha$ maka $\mathrm{H} 0$ diterima dan Ha ditolak dan sebaliknya jika $\mathrm{F}$ signifikan $<\alpha$ maka $\mathrm{H} 0$ ditolak dan Ha diterima.

c. Koefisien Determinasi

Koefisien determinasi digunakan untuk mengukur sejauh mana kemampuan model dalam menerangkan variasi variabel terikat. Nilai $\mathrm{R}^{2}$ berada diantara nol sampai dengan satu. Semakin mendekati nilai satu menunjukkan semakin kuatnya kemampuan dalam menjelaskan perubahan variabel bebas terhadap variasi variabel terikat.

d. Koefisien Korelasi

Koefisien korelasi (R) digunakan untuk mengetahui hubungan antara dua atau lebih variabel independen $\left(\mathrm{X}_{1}\right.$, dan $\left.\mathrm{X}_{2}\right)$ terhadap variabel dependen $(\mathrm{Y})$ secara serentak.Dalam hal ini mengukur hubungan antara variabel independen $\left(\mathrm{X}_{1}\right.$, dan $\left.\mathrm{X}_{2}\right)$ secara serentak terhadap variabel dependen (Y).Nilai $\mathrm{R}$ berkisar antara 0 sampai 1 , nilai semakin mendekati 1 berarti hubungan yang terjadi semakin kuat, sebaliknya nilai semakin mendekati 0 maka hubungan yang terjadi semakin lemah.

\section{HASIL PENELITIAN DAN PEMBAHASAN}

\section{A. HASIL PENELITIAN}

1. Uji Normalitas

Ghozali (2009:107) uji normalitas bertujuan untuk menguji apakah dalam model regresi, variabel terikat dan variabel bebas keduanya memiliki distribusi normal atau tidak. Model regresi yang baik adalah memiliki distribusi data normal atau mendekati normal.

Tabel 4.1 Hasil Uji Normalitas

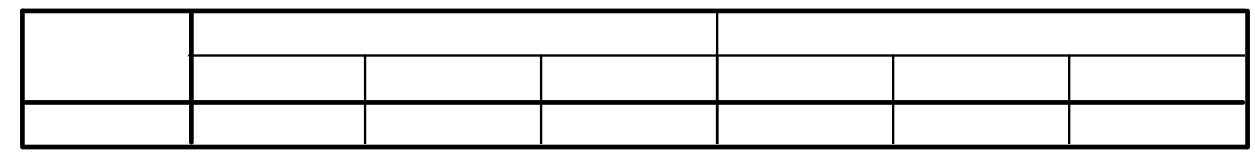

Uji normalitas menggunakan Uji Kolmogorov Smirnov, dimana hasil pengujian menunjukan bahwa residual error data diatas signifikansi $5 \%$ atau 0.137 , sehingga dapat disimpulkan bahwa residual error data terdistribusi dengan normal.

2. Uji Multikolinearitas

Ghozali (2009:25), uji multikolinearitas bertujuan untuk menguji apakah dalam model regresi ditemukan adanya korelasi yang tinggi atau sempurna antar variabel bebas/independen.Model regresi yang baik seharusnya tidak terjadi korelasi di antara variabel bebas.Jika variabel bebas saling berkorelasi, maka variabel-variabel ini tidak ortogonal. Apabila terjadi korelasi antara variabel bebas, maka terdapat problem multikolinearitas pada model regresi tersebut. 
Tabel 4.2 Hasil Uji Multikolinearitas

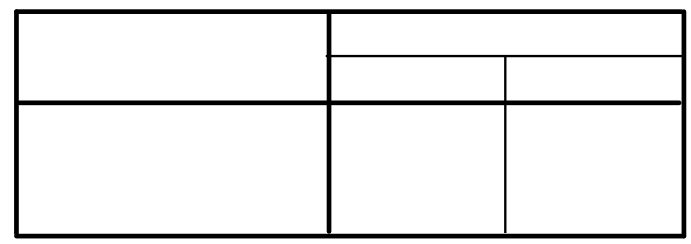

Dari tabel 4.2 terlihat bahwa tidak ada variabel bebas yang memilki nilai tolerance kurang dari 10. Hasil uji VIF juga menunjukan hal yang sama yaitu tidak ada satupun variabel independen yang memiliki VIF lebih dari 10. Sehingga dapat disimpulkan bahwa tidak terjadi multikolinearitas antar variabel bebas dalam persamaan regresi.

\section{Uji Autokorelasi}

Autokorelasi adalah korelasi (hubungan) yang terjadi di antara anggota-anggota dari serangkaian pengamatan yang tersusun dalam rangkaian waktu atau tersusun dalam rangkaian ruang.Autokorelasi bertujuan untuk menguji apakah dalam suatu model regresi linier ada korelasi antara kesalahan pengganggu pada periode $t$ dengan kesalahan pada periode $t-1$ (sebelumnya).Jika terjadi korelasi, maka dinamakan terjadi problem autokorelasi (Ghozali, 2009:79).Pengujian ini dilakukan dengan menggunakan uji Durbin-Watson (DW-test).

\section{Tabel 4.3 Hasil Uji Autokolerasi}

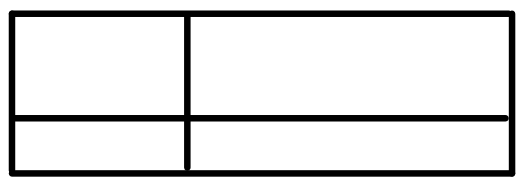

\section{Sumber : Output SPSS Version 17.0}

Dari pengujian Durbin-Watson dalam penelitian ini dihasilkan nilai DW sebesar 1.369. Nilai ini dibandingkan dengan nilai tabel menggunakan signifikasi 5\%, jumlah data 64 (n) dan jumlah variabel independen $2(\mathrm{k}=2)$, maka terletak diantara batas atas $(\mathrm{du}=1,65)$ dan batas bawah $(\mathrm{dl}=1,51)$. Oleh karena nilai DW 2.098 lebih besar dari batas atas $(\mathrm{du})$ 1,65 dan kurang dari 2,3383 (4-du) maka dapat disimpulkan bahwa dalam persamaan regresi ini tidak terdapat autokorelasi.

\section{Uji Heteroskedastisitas}

Ghozali (2001: 69)Uji heteroskedastisitas ditujukan untuk menguji apakah dalam model regresi terjadi ketidaksamaan variance dan residual satu pengamatan ke pengamatan yang lain. Jika variance dari residual satu pengamatan ke pengamatan yang lain tetap, maka disebut homoskedastis dan jika berbeda disebut heteroskedastisitas. Model regresi yang baik adalah yang homoskedastisitas atau tidak terjadi heteroskedastisitas.Cara untuk mendeteksi ada atautidaknya heteroskedastisitas dapat diketahui dengan menggunakan Uji Glesjer. 
Tabel : 4.4 Hasil Uji Heteroskedastisitas

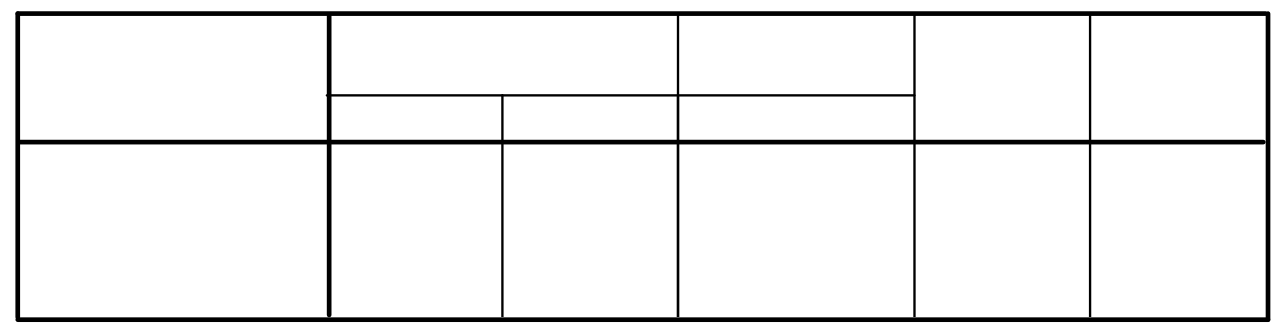

\section{Sumber : Output SPSS Version 17.0}

Dari tabel diatas dan dengan menggunakan Uji Glesjer, maka hasil pengujian menunjukan bahwa setiap variabel independen memiliki signifikasi diatas 5\% terhadap residual errornya, sehingga dapat disimpulkan bahwa varians data penelitian bebas gejala heteroskedastisitas.

Analisis regresi dalam penelitian ini digunakan untuk menguji hipotesis penelitian.Tabel 4.5 di bawah merupakan hasil pengujian untuk menguji pengaruh rasio keuangan terhadap pembayaran dividen pada perusahaan manufaktur. Berdasarkan hasil analisis regresi diperoleh koefisien untuk variabel Return On Equity sebesar 1.100,variabel Debt to Equity Ratio sebesar 0.001, variabel Current Ratio sebesar -0.0219 dan konstanta sebesar 2.584 dari koefisien-koefisien tersebut diperoleh model regresi sebagai berikut:

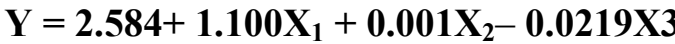

Persamaan regresi linier berganda tersebut di atas dapat di interprestasikan sebagai berikut :

1. Return On Equity mempunyai pengaruh positif terhadap pembayaran dividen. Setiap peningkatan satu satuan pada ROE, maka akan berdampak pada kenaikandividen sebesar 1.100 .

2. Debt to Equity Ratio mempunyai pengaruh positif terhadap pembayaran Dividen. Setiap peningkatan satu satuan pada DER, makaakan berdampak pada kenaikan dividen sebesar 0.001 .

3. Current Ratio mempunyai pengaruh negatif terhadap pembayaran Dividen. Setiap kenaikan satu satuan pada Current Ratio, maka akan berdampak pada penurunan sebesar 0,0219 .

Tabel 4.5 Model Regresi Berganda

\begin{tabular}{|l|l|l|l|l|l|}
\hline & \multicolumn{2}{|l|}{} & & & \\
\cline { 2 - 5 } & & & & & \\
\hline & & & & & \\
& & & & & \\
\hline
\end{tabular}

Sumber : Output SPSS Version 17.0

Tabel 4.5 di atas menunjukan pengaruh Return On Equity, Debt to Equity Ratio, dan Current Ratio terhadap pembayaran Dividen yang dapat dijabarkan sebagai berikut : 


\section{Uji Parsial}

Uji t digunakan untuk mengetahui pengaruh masing-masing variabel bebas yaitu Return On Equity (X1), Debt to Equity Ratio (X2), Current Ratio (X3) terhadap variabel terikat yaitu Dividen (Y).Hasil pengujian secara parsial diperoleh tingkat signifikansi Return On Equity terhadap Dividensebesar $0.000<0.05$ yang berarti hipotesis $\mathrm{Ha}_{1}$ yang menyatakan adanya pengaruh yang nyata Return On Equity terhadap pembayaran Dividenditerima,Sedangkan tingkat signifikansi Debt to Equity Ratio terhadap pembayaran Dividen 0.959>0.05 yang berarti hipotesis $\mathrm{Ha}_{2}$ yang menyatakan adanya pengaruh yang nyata Debt to Equity Ratio terhadap pembayaran Dividen ditolak, dan Current Ratio yang tingkat signifikansinya terhadap pembayaran Dividen sebesar $0.517>0.05$ yang berarti hipotesis Ha3juga ditolak. hal ini berarti dominannya rasio keuangan Return On Equity mempengaruhi pembayaran Dividen.

2. Uji Simultan

Uji $\mathrm{F}$ digunakan untuk mengetahui ada tidaknya pengaruh secara bersama-sama variabel bebas dengan variabel terikat. Berdasarkan data pengolahan variabel penelitian, uji $\mathrm{F}$ dengan probabilitas value dapat dilihat dari probabilitas value dibandingkan dengan 0,05 hipotesis diterima jika probabilitas $<0,05$.

Tabel 4.6 Hasil Uji F

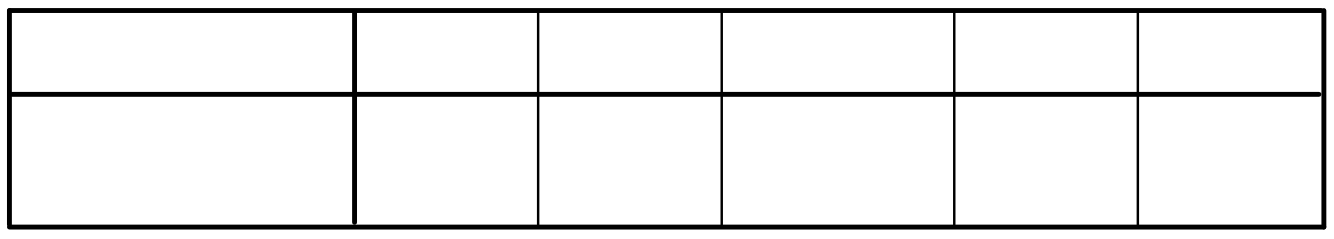

Sumber : Output SPSS Version 17.0

Pada tabel 4.6 di atas dapat dilihat bahwa hasil uji $\mathrm{F}$ menunjukkan nilai $\mathrm{F}$ hitung sebesar 10.046 dengan signifikansi sebesar 0.000. Nilai signifikansi tersebut lebih kecil daripada 0.05 sehingga hipotesis $\mathrm{Ha}_{4}$ dapat diterima, hal ini berarti secara bersama-sama Rasio keuangan berupa Return On Equity, Debt to Equity Ratio, dan Current Ratio berpengaruh terhadap pembayaran Dividen.

3. Koefisien Korelasi dan Determinasi

Koefisien determinasi $\left(\mathrm{R}^{2}\right)$ digunakan untuk mengetahui besarnya pengaruh semua variabel independen secara bersama-sama, yaitu Rasio keuangan berupa Return On Equity, Debt to Equity Ratio, dan Current Ratio terhadap Dividen.

Menurut Suharyadi dan Purwanto (2007:465) Koefisien determinasi adalah bagian dari keragaman total variabel tak bebas $\mathrm{Y}$ (variabel yang dipengaruhi atau dependent) yang dapat diterangkan atau diperhitungkan oleh keragaman variabel bebas X (variabel yang mempengaruhi atau independent). Jadi koefisien determinasi adalah kemampuan variabel $\mathrm{X}$ (variabel independent) mempengaruhi variabel $\mathrm{Y}$ (variabel dependent). Semakin besar koefisien determinasi menunjukan semakin baik kemampuan $\mathrm{X}$ menerangkan $\mathrm{Y}$. 
Tabel 4.7 Hasil Koefisien Determinasi

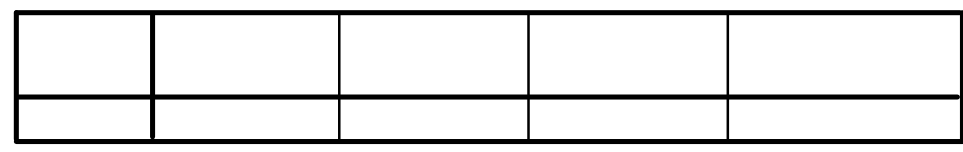

\section{Sumber : Output SPSS Version 17.0}

Tabel 4.7 di atas menunjukan nilai koefisien determinasi sebesar 0.523 atau $52.3 \%$, yang berarti bahwa hubungan antara variabel dependen dan variabel independen adalah sedang. Sedangkan koefisien determinasi sebesar 0.274 menunjukan bahwa kontribusi variabel independen adalah sebesar $27.4 \%$ dan sisanya dijelaskan oleh faktor-faktor lain yang tidak dimasukkan dalam penelitian ini.

\section{B. Pembahasan Hasil Penelitian}

Berdasarkan analisis regresi diperoleh hasil untuk variabel Return On Equity sebesar 1.100, variabel Debt to Equity Ratio sebesar 0.011, variabel Current Ratio sebesar -0,219 dan konstanta sebesar 2.584. Current Ratio mempunyai pengaruh negatif terhadap . Setiap penurunan satu satuan, maka akan berdampak pada penurunan pembayaran dividen sebesar 0,219. Return On Equity mempunyai pengaruh positif terhadap pembayaran Dividen. Setiap peningkatan satu satuan, makaakan berdampak pada peningkatan pembayaran dividen sebesar 1.100. Dan Debt to Equity Ratio mempunyai pengaruh positif terhadap pembayaran dividen, setiap peningkatan satu satuan, berdampak pada pembayaran dividen sebesar 0.011.

Hasil pengujian secara parsial diperoleh tingkat signifikansi Return On Equity terhadap pembayaran dividen sebesar $0.000<0.05$ yang berarti hipotesis $\mathrm{Ha}_{1}$ yang menyatakan adanya pengaruh Return On Equity terhadap pembayaran dividen diterima,sementara tingkat signifikansi Debt to Equity Ratio terhadap pembayaran dividen sebesar $0.959>0.05$ yang berarti hipotesis $\mathrm{Ha}_{2}$ yang menyatakan adanya pengaruh yang nyata Debt to Equity Ratio terhadap pembayaran dividen ditolak, untuk Current Ratio diperoleh tingkat signifikasi $0.517>0.05$ yang berarti hipotesis Ha3 yang menyatakan adanya pengaruh terhadap pembayaran dividen ditolak.

Hasil uji F menunjukkan nilai $\mathrm{F}$ hitung sebesar 10.046 dengan signifikansi sebesar 0.000. Nilai signifikansi tersebut lebih kecil daripada 0.05 sehingga hipotesis $\mathrm{Ha}_{4}$ diterima, hal ini berarti secara bersama-sama Rasio keuangan berupa Return On Equity, Debt to Equity Ratio dan Current Ratio mampu mempengaruhi pembayaran Dividen pada perusahaan manufaktur yang menjadi objek dalam penelitian ini.

\section{KESIMPULAN DAN SARAN}

\section{A. Kesimpulan}

Berdasarkan hasil analisis data dan pengujian hipotesis yang telah diuraikan pada bab sebelumnya, maka diperoleh kesimpulan mengenai pengaruh rasio keuangan (Return On Equity, Debt to Equity Ratio, Current Ratio) terhadap pembayaran dividen sebagai berikut :

1. Secara parsial menunjukan bahwa variabel Return On Equity berpengaruh signifikan terhadap pembayaran Dividen.

2. Secara parsial terhadap variabel Debt to Equity Ratio tidak mempunyai pengaruh yang signifikan terhadappembayaran Dividen.

3. Secara parsial menunjukan variabel Current Ratio tidak mempunyai pengaruh yang signifikan terhadap pembayaran Dividen. 
4. Secara simultan Return On Equity, Debt to Equity Ratio, dan Current Ratiopengaruh yang positifatau signifikan terhadap pembayaran Dividen.

\section{B. Saran}

Berdasarkan hasil kesimpulan dari penelitian tersebut di atas, maka diajukan saran sebagai berikut:

1. Hasil penelitian menunjukan bahwa kemampuan variabel Return On Equity, Debt to Equity Ratio, dan Current Ratio masih kurang oleh karena itu diperlukan pengujian lebih lanjut terhadap faktor-faktor lain seperti menambahkan variabel lain dalam hal ini rasio keuangan lain seperti Net Profit Margin (NPM), Return On Investment (ROI), Debt Ratio (DR) dalam memprediksi kemampuan pembayaran Dividen pada perusahaan manufaktur.

2. Hasil penelitian juga menunjukan bahwa secara parsial Debt to Equity Ratio dan Current Ratio tidak memiliki pengaruh terhadap pembayaran Dividen, jadi bagi pengembangan penelitian selanjutnya agar memperpanjang periode penelitian dan tolak ukur, sehingga dapat diketahui pengaruh secara lebih rinci.

3. Diharapkan informasi ini dapat dimanfaatkan bagi pihak-pihak yang berkepentingan.

\section{DAFTAR PUSTAKA}

Sawir,Agnes, 2005, Analisis Kinerja Keuangan dan Perencanaan KeuanganPerusahaan, Gramedia Pustaka Utama, Jakarta.

Wilujeng,Ani, 2005, Analisis Pengaruh Kinerja Keuangan Terhadap Kebijakan Dividen Kas, Skripsi, Jurusan Akuntansi, Fakultas Ekonomi, Universitas Brawijaya, Malang.

Anton Harry Poerwadi, 2002, Analisis Variabel-variabel yang Mempengaruhi Kebijakan Pembayaran Dividen, Program Studi Manajemen, Tesis, Pascasarjana, Universitas Brawijaya, Malang.

Amin Widjaja Tunggal, 2000, Dasar-Dasar Analisis Laporan Keuangan, Penerbit Rineka Cipta,Jakarta

Baridwan, Zaki, 2000, Intermediate Acoounting, Edisi Ketujuh, BPFE, Yogyakarta.

Brealey, Richard A., Stewart C. Myres, dan Alan J. Marcus, 2004, Fundamentals of Corporate Finance, Edisi Keempat, The McGraw-Hill, New York.

Dwi Prastowo dan Rifka Juliaty, 2002, Analisis Laporan Keuangan: Konsep dan Aplikasi, UPP AMP YKPN, Yogyakarta..

Gitman, Lawrence J. 2003, Principles of Managerial Finance, Edisi Kesepuluh, Addison Wesley Publishing Company, Massachusetts.

Indriyo Gitosudarmo dan Basri, 2000, Manajemen Keuangan, Edisi Ketiga, BPFE, Yogyakarta.

ImamGhozali. 2009. Ekonometrika: Teori, Konsep, dan Aplikasi dengan SPSS 17. Badan Penerbit Universitas Diponegoro, Semarang. 
IR. Wijaya, 2001, Analisis Statistik dengan Program SPSS 10.00, Alfabeta, Bandung.

Kania, Sharon dan Frank W. Bacon, 2005, What Factors Motivate The Corporate Dividend Decision?, Journal of Finance, Volume 1, 97, Business Index ASAP, Farmville, VA: Longwood University,(http://web2.infotrac.galegroup.com).

Mamduh M. Hanafi dan Abdul Halim,2005. Analisis Laporan Keuangan, Edisi kedua, Penerbit UPP AMP YKPN. Yogyakarta.

Nasharuddin Mas, 2002, Pengaruh Kinerja Keuangan Terhadap Perubahan Dividen (Studi pada Perusahaan Manufacturing Listed di BEJ), Program Studi Manajemen, Pascasarjana, Universitas Brawijaya, Malang.

R. Gunawan Sudarmanto, 2005, Analisis Regresi Linier Ganda dengan SPSS, Edisi Pertama, Graha Ilmu, Yogyakarta.

Ridwan S. Sunjaya dan Inge Barlian, 2003, Manajemen Keuangan, Jilid Satu, Edisi Kelima, Literata Lintas Media, Jakarta

Robbi Anshori, 2004, Pengaruh Variabel Keuangan Terhadap DPR (Studi Kasus pada Perusahaan yang Listing di BEJ), Skripsi, Jurusan Akuntasi, Fakultas Ekonomi, Universitas Brawijaya, Malang. 